\title{
Beyers Naudé: South Africa's Bonhoeffer? Celebrating the centenary of the birth of Beyers Naudé - 1915-2015
}

\author{
De Gruchy, John \\ University of Cape Town \\ john@degruchy.co.za
}

\begin{abstract}
When Dietrich Bonhoeffer's friend and biographer Eberhard Bethge visited South Africa in 1973, he commented that Beyers Naudé was South Africa's Bonhoeffer. In this essay I explore what Bethge meant and whether it is a description that helps us understand Naudé's legacy better. I do this in three parts. Firstly I offer a biographical comparison Bonhoeffer and Naudé. Secondly I suggest why Bethge's comment was a carefully considered opinion formed over at least ten years. Thirdly I show that Bethge's interest in Naudé and the church struggle in South Africa continued long after his visit to South Africa. I conclude that whatever their similarities and differences they became models of a new style of being Christian in the world. What unites them as human beings and Christians is their integrity in word and action, confession and resistance.
\end{abstract}

Keywords

Beyers Naudé, Dietrich Bonhoeffer, Eberhard Bethge, Church struggle, Being Christian

When Dietrich Bonhoeffer's friend and biographer Eberhard Bethge visited South Africa in 1973, he confided in the author that Naudé was South Africa's Bonhoeffer. ${ }^{1}$

As a contribution to the celebration of the centenary of Oom Bey's birthday, and also to foster the connection between the Beyers Naudé Centre and the

1 The Bethges visited South Africa from $4^{\text {th }}$ February to $9^{\text {th }}$ March 1973 at the invitation of the South African Council of Churches. 
Bonhoeffer Research Unit within it, I wish to explore what Bethge might have meant by his comment. Is it an appropriate description, one that helps us understand Beyers Naudé's legacy better? After all, Oom Bey was primarily a South African prophet, pastor and ecumenical leader in the struggle against apartheid. He was not a clone of a German theologian and martyr.

So what did Bethge have in mind when he made his comment? Was he sufficiently familiar with Naudé's life and witness to do so? Does it enhance or detract from Naudés stature and significance in his own right? And does critical reflection on the question contribute in any way to Christian witness and doing theology today in South Africa or elsewhere?

I will seek some answers to these questions in three sections. In the first I will provide a biographical sketch comparing Bonhoeffer and Naudé in order to highlight some similarities and differences in their respective stories. In the second section I will show why Bethge's comment about Naudé was not just an "off-the-cuff” remark, but also a carefully considered opinion that had developed prior to his visit to South Africa in 1973. In the third section, I will show how Bethge's interest in Naudé and the church struggle in South Africa continued long after his visit.

\section{A comparative biographical sketch}

Bethge more than anyone else knew Bonhoeffer's story from the inside, as his monumental biography demonstrates. ${ }^{2}$ But he did not know very much about Naudé's story ${ }^{3}$ except as it related to his role in the church struggle in South Africa. Bethge was not really interested in comparing them beyond their respective roles in their respective struggles against Nazism and apartheid. If he had done so, he might have been surprised to discover resemblances that reinforce his statement that "Beyers Naudé is South Africa's Bonhoeffer." But he would also have discovered some significant differences.

2 See Eberhard Bethge, Dietrich Bonhoeffer: A Biography (Minneapolis: Fortress Press, 2000).

3 See Colleen Ryan, Beyers Naudé Pilgrimage of Faith. (Cape Town: David Philip, 1990) 
Both Bonhoeffer and Naudé had deep roots in the "aristocracy" of their respective countries, and grew up as part of their cultural elite. They were not born on the "wrong side of the tracks," but into privilege, though Dietrich more so than Beyers. This ensured a solid start to life and eventually a good education despite the historical context within which they lived. For both of them grew up in the shadow of wars, which led to the defeat of their nations and resulted in years of economic depression even if not hardship for their own families on the scale it affected others.

The Anglo-Boer War, in which the British colonial army not only defeated the Afrikaner Republics but also used illegal weapons and humiliating tactics in doing so, evoked deep anger and resentment amongst Afrikaners, not least in the Naudé family. Beyers was named after one of the leading Boer Generals who resisted the British to the end. In the aftermath, the Naudé family became firm supporters of Germany in the First World War and sympathetic to Germany's cause in the Second. Naude's father was a leading member of the Afrikaner Broederbond, a member of the National Party, a supporter of apartheid, encouraged Beyers to do the same. This was reinforced by his mother's decidedly anti-British and segregationist views.

Bonhoeffer, who was ten years Naudés senior, reached maturity in the aftermath of the First World War in the course of which one of his brothers died on the battlefield. His family was traumatised by his death and angered by the humiliation of the Versailles Treaty following Germany's defeat. As a result Bonhoeffer became an ardent patriot. But the Bonhoeffer family did not support the rise of National Socialism after the Depression and the failure of the Weimar Republic; on the contrary they were opponents of Hitler from the beginning.

Both Dietrich and Beyers had very domineering fathers and were strongly under their influence. But whereas Bonhoeffer's family was on the periphery of the life of the German Evangelical church and his father a sceptical scientist, something that accounts for Dietrich's enquiring and critical mind, Naudé's father, was a leading minister in the Dutch Reformed Church and his family was deeply embedded in the life of the church. There was little space for critical thinking in the Naudé household, only acceptance of unquestioned values and deep faith in the God of providence who had brought the Afrikaner nation into being. All of which served to reinforce 
Beyer's acceptance of Nationalist aspirations and policies. But ironically, Naudé would later use the values used in support of Afrikaner liberation from British oppression in his rejection of Afrikaner Nationalism and support for black liberation.

Both Bonhoeffer and Naudé felt called to become ministers at an early age. In Bonhoeffer's case his decision surprised his family, and was decidedly against his father's wishes. His early spiritual formation, shaped solely by the influence of his mother and the piety of his Moravian nanny, not much connected to the life of the church. Dietrich had to discover the church for himself. But what would have been inconceivable for the strictly antiCatholic Calvinist Naudé family was that Bonhoeffer did so during his student sojourn in Rome when he attended Holy Week and Easter services in St. Peter's Basilica.

Naudé's decision to enter the ministry was no surprise at all to his family, though he first considered studying law. He had an evangelical conversion after listening to his father's preaching during Pentecost in May 1930, and his decision to become a minister had his father's blessing and encouragement. But while the evangelical piety and nationalist spirit of both parents was deeply embedded in his soul, as a student he had already begun to assert his independence. Dietrich had done this by choosing to be a theologian; Naudé did so by beginning to question his parent's piety.

Bonhoeffer first studied theology at Tübingen, but continued a year later in Berlin where he came under the influence of some of the leading Protestant theologians in Germany, some Reformed, others Lutheran, but especially the liberal Adolf von Harnack. All of them were nationalists in their political orientation, all were supporters of the Kaiser, and if later critical of National Socialism, they were not outspoken in their opposition. They were also critical of the neo-Orthodoxy of Karl Barth whose "dialectical theology" was "unscientific" and whose opposition to Hitler too radical. Dietrich warmed to von Harnack and was an excellent student, but he also came under the spell of Barth, even though Barth was teaching in Bonn not Berlin.

Naudé studied theology at Stellenbosch, where his teachers were, with very few exceptions, all strict neo-Calvinists (Kuyperians), and opponents of liberal theology, evangelical missionary piety and Karl Barth, as well 
as being ardent Afrikaner nationalists. They were also not particularly inspiring teachers, their main task being to defend conservative theological and political positions rather than engage them critically. An exception was BB Keet who was critical of apartheid and, though a Calvinist, was sympathetic towards Barth who provided an alternative Reformed theology to that of the Kuyperians.

Beyers was also influenced by the legacy of Johannes du Plessis, a former professor of missions, who had been sacked from his post for heresy, but clearly also on political grounds. Unlike the prevailing Dutch Reformed missionary ethos that supported segregationist policies, the missionary spirit represented by du Plessis was different. ${ }^{4}$ In fact, Naudé's "conflict with the South African political system," as Jaap Durand notes, "originated, in an intensive missionary involvement during the critical pre-Cottesloe years. His rebellion," Durand continues, "did not come from a clear and well-defined Reformed theological system, but from a deep Christian commitment to the missionary calling of the church." 5 This was strengthened by his marriage to Ilse Weder, the daughter of a Moravian missionary, and time spent at the Genadendal Mission station in the Western Cape. It was there that he had his first adult experience of meeting "coloured" people on an equal basis.

Unlike the young Beyers, Dietrich was a brilliant student who completed his doctoral dissertation at the age of 21 . And his future as an academic theologian was virtually assured when, a few years later, he published his Habilitationsschrift entitled Act and Being. But except for a short period as a part-time honorarylecturer in theology in Berlin, Bonhoeffer never became a university professor. Instead he was ordained and served as a pastor in various congregations, including in Barcelona, Berlin, and London, and then Director of a Confessing Church Preachers' Seminary for a few years, but he was by then already being drawn into the underground opposition to Hitler.

4 Jaap Durand, "Afrikaner Piety and Dissent", in Resistance and Hope. Villa-Vicencio and De Gruchy (eds), 49-50.

5 Jaap Durand, "Afrikaner Piety and Dissent", in Resistance and Hope. Villa-Vicencio and De Gruchy (eds), 48. 
Naudé was an intelligent but not brilliant student and, with the exception of Keet's teaching, was not particularly stimulated by his studies. He did not proceed to do his doctorate and had no intention of becoming an academic theologian. As the years passed he became theologically astute, but this was not so initially. He was at heart a pastor whose well-constructed sermons, preaching and biblical teaching was widely acknowledged and influential, especially amongst students. His career path was clearly within the church and it was there that he soon excelled in several congregations. He soon climbed the ladder of influence in the DRC's leadership, helped by his membership within the Broederbond but also by his outgoing, warm personality and leadership qualities that were already in evidence during his student years. Had he toed the line his chosen path could easily have become one that led to high office in government and the state.

From his student days through his years as a DRC leader, his founding and leading of the Christian Institute, and his later role as General Secretary of the South African Council of Churches Naudé was skilled at institutional diplomacy and leadership, albeit one who stood his ground on matters of conscience. Bonhoeffer also knew how to "play politics" when that was required, but it is difficult to conceive of him becoming a bishop or a cabinet minister. He never became a church leader in any formal sense. Both his age and his critical views ensured that he was always on the periphery, even when he was engaged in the church struggle and, at least outside his own church in Germany, a leading voice in the church struggle and ecumenical movement.

So what changed the direction of Bonhoeffer and Naudé's lives and ministry? In his prison letters Bonhoeffer wrote that he had only changed once. ${ }^{6}$ This was due to the influence of his father, who helped turn him "from the phraseological to the real," and to his early travels abroad first as a student to Italy and North Africa, and then to the United States, which broadened his vision beyond the narrow confines of Germany and led to his conversion to a very different Christian faith than that which he had previously imbibed. As a student in New York he discovered the real meaning of Christian discipleship, and was exposed to African-American

6 Dietrich Bonhoeffer, "Letters and Papers from Prison", in Dietrich Bonhoeffer Works, John W de Gruchy (ed), vol. 8. (Minneapolis: Fortress Press, 2010), 358. 
Christianity, which he found more authentically Christian than the liberal Protestantism of white Christianity. It was also the black American narrative, with its roots in slavery that first made him see reality from the margins and underside of the dominant American narrative.

There were several factors that led to Naudés conversion from Afrikaner Nationalism and apartheid. In addition to the on-going influence of Keet, another was the influence of Doctor Ben Marais, the senior minister of the congregation in Pretoria where Naudé was, for a time, an assistant minister. In 1952 Marais published his book Die Kleurkrisis in die Weste in which Naudé encountered the voices of many leading theologians, including Barth, who condemned racial segregation. The debate that raged throughout the DRC as a result deeply affected Naudé.

In 1953 Beyers was part of a DRC youth delegation that went on a study tour to Europe, spending time largely in the Netherlands and Germany. This was when he began to discover the ecumenical church. While he tried to defend apartheid, he was continually challenged on the subject not least by members of the Reformed churches in Holland. It was then that he also became aware of the story of the German Kirchenkampf and probably also, for the first time, heard about Dietrich Bonhoeffer, Soon after he became a dominee in Potchefstroom and it was there that he attended a meeting of the Reformed Ecumenical Synod, an ecumenical body albeit one critical of the World Council of Churches and also of liberal theology. But even this largely conservative ecumenical body voiced its disquiet about of apartheid, and did so on the basis of Reformed theology. In addition, while he was in Potchefstroom Naudé met several white Dutch Reformed missionaries within the black communities, and from them he learnt first-hand of the hardships and injustices of apartheid.

Then, in 1960, the year after Naudé was inducted as the minister of the Aasvoëlskop congregation in Johannesburg, the church attended by many of Afrikaner's elite, the Sharpeville Massacre occurred. This led, the next year, to the convening by the WCC member churches' of the Cottesloe Consultation. In terms of Naudé's life, the rest is history, but it is also the story that was known to Eberhard Bethge and which led him to make his comment that "Beyers Naudé's is South Africa's Bonhoeffer," to which I will now return. But we must note that in doing so, that the 
name of Dietrich Bonhoeffer has not really been mentioned in relation to the changes that took place in Naudé's life. If you read Murray Coetzee's massive and excellent study of Beyers Naudé's role in the struggle against "apartheidsteologie" up to 1974, you will look in vain for any reference to Bonhoeffer.?

At the same time, Bonhoeffer's story was by now well known to Naudé. When I was a student in Chicago in 1963-64, he visited the United States and telephoned me because I was one of the students who had received a WCC scholarship and he had been given the task to monitor our progress on its behalf. On the phone he told me about the Christian Institute and invited me to visit him on my return to South Africa, which I did in August 1964. He asked about my Master's dissertation, which I had written in Chicago and when I mentioned that it was partly on Bonhoeffer's theology and racism, he immediately became very interested, asking me to write some articles for the CI journal Pro Veritate based on the subject. Bonhoeffer's name clearly rang some important bells for him. Bonhoeffer might not have been a life-changing agent in Naudé's early story, but he did become an important example for him as his story began to unfold in the nineteenseventies. And, as we shall see, Naudé in turn played an important role in enabling the German church to recover, through Beyers Naudé, something of the spirit of the Confessing Church in return.

One final comment is necessary to complete this comparative biographical sketch. Bonhoeffer died aged 39 as a victim of the Gestapo, was regarded as a traitor long after the War ended, and was only acknowledged as a martyr much later. Naudé, by contrast, lived long enough not only to see the end of apartheid, participate in the process of transition, but also be honoured for his life of resistance.

\section{Bethge and Naudé prior to 1973}

In my biography of Eberhard Bethge, Daring, Trusting Spirit, I describe how Bethge had been interested in the church struggle against apartheid

7 Murray Hermanus Coetzee, Die "Kritiese Stem" teen apartheidsteologie in die Ned Geref Kerk (1905-1974): 'n analise van bydraes van Ben Marais en Beyers Naudé (Wellington: Bybel-Media, 2010). 
since the early nineteen sixties. ${ }^{8}$ Bethge's awareness of the emerging situation and the possible relevance of Bonhoeffer is already evident in his Chicago Alden-Tuthill Lectures in 1961. Commenting in those lectures on "Bonhoeffer's hot theological discussions with Geneva and with Faith and Order in 1934 and afterward," Bethge remarked that they "would make a good and penetrating textbook for our judgment of the present crisis between the churches in South Africa and the relation of Geneva to this crisis." The crisis was, of course, the situation following the Sharpeville Massacre in March 1960, when the Anglican Archbishop Joost de Blank insisted that the Dutch Reformed Church be excommunicated from the World Council of Churches. ${ }^{10}$

Later in his Chicago lectures, Bethge returned to this subject with the comment that Bonhoeffer himself had "presented the Oekumene with a most delicate demand to accept the condemnation of the heretics, exactly as the archbishop of Cape Town does today." ${ }^{11}$ In fact it was largely because of Archbishop de Blank's condemnation of the Dutch Reformed Church, which was then still a member of the WCC that led to the convening of Cottesloe Consultation in which not only De Blank but also Naudé, who met for the first time, played a key role.

Bethge's awareness of what was then happening in South Africa was largely because at that time he was a pastor of two German-speaking Lutheran congregations in London In that capacity he moved in ecumenical circles where there was growing concern about apartheid. Moreover, the British media (unlike the German), especially after Sharpeville, was increasingly focussed on what was happening in South Africa. In notes Bethge kept of a church meeting he attended in London, he refers several times to people involved in the emerging church struggle against apartheid, among them Chief Albert Luthuli, Bishop Ambrose Reeves of Johannesburg, Father

8 John W de Gruchy, Daring, Trusting Spirit: Bonhoeffer's Friend Eberhard Bethge (London: SCM; Minneapolis: Fortress, 2005), 158-175.

9 Eberhard Bethge, "The Challenge of Dietrich Bonhoeffer's Life and Theology," Chicago Theological Seminary Register, vol 51, no 2, February (1961):3.

10 See John W de Gruchy with Steve de Gruchy, The Church Struggle in South Africa, $25^{\text {th }}$ Anniversary revised and expanded edition (London: SCM; Minneapolis: Fortress 2004 and 2005), 60-62.

11 Bethge, “The Challenge," 25. 
Trevor Huddleston, Canon John Collins, and Archbishop de Blank. ${ }^{12}$ The fact that Beyers Naudés name does not appear can be attributed to the fact that he was virtually unknown at the time in Britain where interest focussed on the English-speaking church leaders in South Africa.

Naudés name only becomes known and increasingly prominent within the international ecumenical world after Cottesloe, and especially after the formation of the Christian Institute in 1963. This was largely a result of the many visits he made to Europe and the United States to talk about the situation in South Africa and the work of the Christian Institute. He was then a regular speaker at ecumenical events where apartheid was on the agenda, and often drew parallels between the church struggle in South Africa and the German Kirchenkampf. In doing so he also cited the Barmen Declaration and Bonhoeffer's role as an example to be followed. In fact, he regarded the Christian Institute as an instrument for establishing a confessing church movement.

Bethge, as someone who had a personal as well as ecumenical interest in the emerging South African church struggle, not least because of his and Bonhoeffer's involvement in the Kirchenkampf, followed these developments at a distance. As yet he had not had any direct experience of the South African context nor, to my knowledge, had he yet met Beyers Naudé. But he did meet Naudé when they both attended the First International Bonhoeffer Congress in Kaiserswerth in 1971, where Naudé was a "lively and very friendly presence," as Clifford Green, a leading Bonhoeffer scholar, recalls. ${ }^{13}$

The fact that Naudé was the only South African present at the founding Congress is, in itself, salutary, for it indicates that by then he recognised more clearly the significance of Bonhoeffer's legacy in his own life and work. But it is equally clear that Naudé was welcomed and engaged by Bonhoeffer scholars at the Congress as the leading voice in the church struggle against apartheid in South Africa and, as such a "Bonhoeffer-like figure." Many of those present, like Bethge himself, were deeply concerned and well

12 The notes, which are very difficult to decipher, are dated $29^{\text {th }}$ May, but the year is not clear.

13 In correspondence with the author, 2 May 2015. 
informed about apartheid and it is safe to assume that Bethge played a role in inviting him to the Congress, and would have had discussions with him while there. As Bonhoeffer's close confidant and biographer, Bethge would have inevitably begun to draw comparisons between Naudé and his martyred friend.

In August that same year, 1971, Isobel and I visited Eberhard and Renate Bethge in Rengsdorf, a small rural town in Germany where Bethge was the director of a Pastoral Seminary for the Evangelical Church of the Rhineland. The purpose of my visit was to consult with Bethge about my doctoral dissertation in which I was working on Bonhoeffer's ecclesiology. The Christian Institute had arranged my trip to Europe, but I was working at the time for the South African Council of Churches and had responsibility for inviting scholars to South Africa who could contribute to the church struggle in the country. With this in mind, while in Rengsdorf, I enquired whether the Bethge's would be willing to visit South Africa, and they immediately and enthusiastically agreed to do so if an invitation was forthcoming. In due course this was arranged, and in February 1973 they arrived in Johannesburg. The next morning I fetched them from their hotel in Braamfontein and took them directly to meet Beyers Naudé.

It was immediately after that meeting that Eberhard made his comment about Naudé being "South Africa's Bonhoeffer." In the light of what I have said, this was not an "off-the-cuff" rhetorical remark made in passing by an ecumenical tourist visiting Beyers Naudé, as many others did who came to his office in Dunwell House in Braamfontein in the nineteen-sixties and seventies. Bethge had already come to this conclusion, at least by 1971 at the Kaiserswerth Congress. He discerned a resonance between Naudé and his friend Bonhoeffer just as he did between the South African political and church situation in which Naudé found himself and that which prevailed in Nazi Germany in Bonhoeffer's day.

Both Bonhoeffer and Naudé became involved in the church struggles in their respective countries against racist ideologies; both ran foul of their respective church authorities because of the stand they took; and both had a remarkable influence on younger theologians and pastors, not in the formal academic setting, but through biblical expositions, lectures and sermons. Both also risked their lives in solidarity with the oppressed; both 
were accused of treason and banned from speaking by the state; and both were secretly involved with those who were seeking to overthrow their respective governing regimes.

In short, whatever their differences by way of personality, theological ability, or their leadership qualities, Bethge regarded Naudé as a kindred spirit to his friend Dietrich. They were not only both Christians by conviction, but also Christians who were willing to take the risk of being faithful witnesses to the gospel against the tyrannies of oppression that confronted their nations. This is why Naudé brought their names together in the way he did. But he not only did so. He also became an important interpreter of Beyers Naudé and the South African church struggle in Germany from then on, just as he had become the interpreter of Dietrich Bonhoeffer and the Kirchenkampf to the rest of the world.

\section{Bethge as interpreter of Beyers Naudé}

The Bethges were not disappointed with their visit to South Africa In his report afterwards, appropriately entitled "A Confessing Church in South Africa?"14 Bethge spoke of his surprise at how much Bonhoeffer's legacy was regarded as important in the country, and the uncanny resemblance between the German Kirchenkampf and the South African church struggle. But, he asked, "how helpful in fact is this example of the Confessing Church?" His answer was ambiguous. On the one hand, the German experience resonated with the thinking of those engaged in the church struggle against apartheid; on the other hand, the situation had too many variables, whether in church, society or politics, to equate it with the German context.

Moreover, whereas the Barmen declaration had avoided any direct reference to the Jews, the Message to the People of South Africa, published by the South African Council of Churches and the Christian Institute in 1968 had

14 See Eberhard Bethge, "A Confessing Church in South Africa: Conclusions from a Visit" in Bonhoeffer: Exile \& Martyr, editors John W de Gruchy (London: Collins 1975), 167-178. Originally published in Evangelische Kommentare, No. 6, ${ }^{\text {th }}$ June 1973; subsequently translated and published by the World Council of Church in English in Study Encounter, (WCC) vol. IX, no. 3, 1973. 
referred to apartheid, whether in church or nation, as a "false gospel." ${ }^{5}$ The critical issue was whether white and black South Africans could find each other in church and society at a time when apartheid was tearing them apart. Thus, while some white Christians were engaged in a struggle partly inspired by the Kirchenkampf, black theologians were developing their own agenda inspired by the Black Consciousness Movement.

During the year following their visit to South Africa, the situation in the country rapidly deteriorated as resistance grew and the armed struggle intensified.

Bethge was often asked to speak on the situation in South Africa within German church circles and to help formulate responses to the growing crisis. As he did for example during Naudé's trial in 1974 for refusing to give evidence before a government commission, investigating the Christian Institute, ${ }^{16}$ and the expropriation of the Federal Theological Seminary in Alice in 1975. Bethge tried hard to inform the leadership of the Evangelical Church in Germany, encouraging them to send protest messages to the regime. ${ }^{17}$

Bethge, mindful of Bonhoeffer's as well as his own position during the Second World War, was particularly interested in the debate about conscientious objection that erupted during 1974 within the South African Council of Churches (SACC) and its member churches. ${ }^{18}$ Though some conscientious objectors were pacifist, the majority of the young white South Africans who refused to do military service often referred to the witness of Bonhoeffer, whose name was also mentioned in debates in Parliament at this time. Bethge found the decision of the SACC "very exciting", giving substance to the debate about the WCC Programme to Combat Racism and making it more relevant. ${ }^{19}$

15 De Gruchy, The Church Struggle in South Africa, 115-26.

16 The Trial of Beyers Naudé: Christian Witness and the Rule of Law. Edition Geneva. Edited by the International Commission of Jurists (London: Search Press).

17 Letter to the author 21.3.75

18 De Gruchy, The Church Struggle in South Africa, 138-48.

19 Letter to the author 19.8.74 
Bethge was particularly intrigued by the development of Black Theology in South Africa, and was aware that Naudé had been influenced by it so much so that the Black Theology Project was housed in the Christian Institute offices. Shortly after he arrived back from his visit Bethge received the third issue of the Journal of Theology for Southern Africa containing one of his own lectures, but also Dr Manas Buthelezi's “Six Theses: Theological Problems of Evangelism in South Africa" in which he called on blacks "to evangelise and humanise" whites in South Africa, ${ }^{20}$ These made a deep impression on Bethge who then used them in his own talks and seminars on South Africa.

Manas Buthelezi, at that time, the director of the Christian Institute in Natal, was a close associate of Beyers Naudé and already known to Bethge through his friends Professor Heinz Eduard Tödt and Dr Ilse Tödt of the University of Heidelberg, where Buthelezi had briefly lectured in 1972. The Tödts were involved on behalf of the Lutheran World Federation in dealing with the South African situation, and over the ensuing years they became increasingly involved with Bethge in Bonhoeffer research. In the summer of 1975 they convened a conference at Heidelberg on theology within the South African struggle in dialogue with Buthelezi. The importance of Bonhoeffer, and of Bethge's interpretation for this dialogue, can be clearly seen from Ilse Tödt's presentation. ${ }^{21}$

The previous October, Bethge led a seminar on Black Theology sponsored by the Evangelical Church in the Rhineland, together with a young Anglican priest, Desmond Tutu. On this occasion Bethge gave the main address in which he favourably compared black theology as a challenge to white racism, to Barth's theology as a critique of liberal bourgeois culture of a previous era. Bethge argued that a relevant theology is one that radically renews our understanding of Christ and the church. ${ }^{22}$ Black theology,

20 Journal of Theology for Southern Africa, no. 3, pp 55-56

21 Tödt, Ilse 1976. Parameter der Friendensforschung und die Theologie Südafrika: Nischer Schwarzer. In Theologi Im Konfliktfeld Südafrika: Dialog mit Manas Buthelezi. Edited by Ilse Tödt. Stuttgart: Ernst Klett Verlag. 214-53.

22 See mimeographed notes entitled "Bericht über das seminar Schwarze Theologie als Versuch einer relevanted Theologie", durchgeführt im Rahmen des PfarrerFortbildungsprogramme der Evangelische Kicrche im Rheinland von 7-11 Oktober, 1974. 
he declared, is a critique of the tribal religion of whites, the religion of privilege, but also a theology that enables us to discern again the liberating power of the gospel.

Bethge's exposition of black theology shows the extent to which he was familiar with its major themes, and also aware of the struggle going on within the churches in South Africa. But we may also say that his encounter with black theology, Beyers Naudé, and the church struggle also made him more aware of the on-going relevance of Bonhoeffer's confessing legacy within his own German context rather than simply on the problems of secularisation and atheism.

Several ecumenical events brought the relation between Christian confession and political action in the struggle against apartheid into greater prominence. These were of considerable interest to Bethge both in terms of South Africa and in enabling him to rethink the relationship between confession and resistance in the German context. The first event was the meeting of the Lutheran World Federation (LWF) in Dar es Salaam in June 1977, which adopted a resolution put forward by Manas Buthelezi that the situation in South Africa be declared a status confessionis. ${ }^{23}$ Then, at the World Alliance of Reformed Churches (WARC) meeting in Ottawa, Canada, the following year, the Alliance declared that a status confessionis existed in South Africa and that apartheid was a theological heresy. ${ }^{24}$ And it was the Dutch Reformed Mission Church that drafted the Belhar Confession of Faith in 1982 that effectively made it a "confessing church." ${ }^{25}$ Bethge recognised the significance of this event when he wrote a brief meditation on the Belhar Confession, significantly dedicated to Beyers Naudé whom he, as a former Barmen-Dahlemite, acknowledged as its pioneer. ${ }^{26}$

23 See From Federation to Communion: The History of the Lutheran World Federation. Jen Holger Schjørring, Prasanna Kumari, Norman A Hjelm (eds) (Minneapolis: Fortress 1997), 399-400

24 "Racism and South Africa". A Statement adopted by the General Council of the WARC, $25^{\text {th }}$ August, 1982. Published in John W de Gruchy \& Charles Villa-Vicencio, Apartheid is a Heresy, 1983. (Grand Rapids: Eerdmans 1983), 168-173.

25 GD Cloete \& DJ Smit, A Moment of Truth: The Confession of the Dutch Reformed Mission Church, 1982 (Grand Rapids: Eerdmans 1984).

26 "Kurze Meditation über das Belhar-Bekenntnis vom Oktober 1982", 151 
Some ten years after his visit to South Africa, at the Kirchentag in Hannover in 1983, Bethge and Lutheran theologian Ulrich Duchrow engaged in a public discussion on confession and resistance in the Third Reich and in South Africa. Bethge recalled how for Barth and Bonhoeffer the Barmen Declaration was a confession of Christ against heresy in the church, not an act of political resistance as it was misrepresented in the Western press. ${ }^{27}$ But, as such, it was also an implicit act of resistance, even though it never actually dealt with the political issues. The failure to recognise this connection between confession and political resistance now undermined the witness of the church in Germany, Bethge argued, and he constantly returned to making this point when discussing South Africa. Bethge stressed the fact that German Protestants had a special responsibility towards South Africa, sharing in its guilt and sharing responsibility for the situation. They could not wash their hands of this legacy. ${ }^{28}$

Bethge's reflections on South Africa had clearly sharpened his understanding of the relation between confession and resistance, and he returned to this theme in his address to the Seattle Assembly in 1984 that celebrated the fiftieth anniversary of the Barmen Declaration. In it he again stressed both the distinction and the connection between Christian confession and political resistance. Confession is not resistance, but public witness "to that Christ who brings God to us in the midst of our lives, to that God who directs our hearts, thoughts, and actions against the false gods and, at the same time, to the victims of those false gods." ${ }^{29}$

The Bethges met Beyers Naudé again in May 1985 when, following his "unbanning" they were together at a conference on South Africa held at the Evangelical Academy in Arnoldsheim. This occasion demonstrated Bethge's continued interest in and commitment to the anti-apartheid struggle. In a letter to the author Bethge mentioned that for two weeks he and his wife had been involved in "a protest march to the SA Embassy to

27 "Südafrika: Das ist mein pervertiertes Gesicht: Gesprach mit Eberhard Bethge und Ulrich Duchrow über Bekenntnis und Widerstand im Dritten Reich und heute in Südafrika 1983. In Bekennen und Widerstehen, Eberhard Bethge 1984. (Munich: Chr. Kaiser Verlag 1984), 180.

28 Bethge, Bekennen und Widerstehen, 198.

29 Eberhard Bethge, "The Confessing Church, Then and Now: The Barmen Declaration, 1934 and 1984”, in The Barmen Confession, Hubert Locke (ed), 219. 
back a petition for the imprisoned 16 in SA waiting for their trial." But, he added, "The papers reported only about police actions and not about the reasons for the actions." ${ }^{30}$

This was the context within which the Kairos Document was drafted in 1985 evoking a great deal of interest amongst church circles in Germany, especially those concerned about South Africa. Bethge, again, was well aware of this development. And gave the opening paper and also the Sunday sermon at a conference on the Kairos Document held in Bad Godesberg in December 1986. ${ }^{31}$ He began by recalling how, in 1933 in Berlin, Barth had challenged the prevailing theology with his fundamentally different understanding of God, and then in 1938, after "Kristallnacht" he had spoken of the need to overcome the political heresy of Nazi ideology. ${ }^{32}$ The Kairos Document, Bethge suggested brought these two together, namely, the theology of the first Commandment, and its political consequences. But what did this mean for Christians in Germany today, he asked? How should the church in Germany respond to the Kairos Document?

This question prompted a third memory of the Nazi period, namely, that of theologians who tried to paralyse the challenge of the Barmen Declaration by raising objections to its "one sidedness". The same danger now presented itself as Germans tried to respond the challenge of the Kairos Document. One danger was to say that the Kairos Document, however appropriate as a call to action in South Africa was theologically flawed from the perspective of good German theology. Another was to think of it as a statement of the "theological left", of those more influenced by Marx than the Bible. But in fact, the Kairos Document was addressing a status confessionis on the basis of biblical theology; it was not inviting endless discussion, but praxis.

Bethge reminded his listeners that the Barmen Declaration had addressed its own kairos in the same way, something recognised also in the witness

30 Letter dated 27.5.85

31 The conference was sponsored by "Plädoyer für eine ökumenische Zukunft" held in Bonn-Bad Godesberg, 5-7 December 1986.

32 Bethge, Eberhard. Die Erfahrungen von Widerspruch zwischen Staatstheologie Kirchentheologie - Prophetischer Theologie - in unserer gengenwärten Situation: auf dem Weg zu einerm Bundesdeucthschen Kairos-Papier. Unpublished document in Bethge's private papers. 
of Beyers Naudé. This was also Bonhoeffer's understanding of a confession of faith. It was not an attempt to state the whole of Christian dogma, but to address a specific issue at a specific time and place. In doing so it drew the boundaries, as at the Reformation, between "true" and "false" church. ${ }^{33}$ Of course, this was dangerous because it could demonise those who disagree with us, a danger to which the Kairos Document was prone. But again, that was the risk of true confession in identifying heresy and seeking to counter it.

Bethge also addressed the criticism that the Kairos Document's theology was pre-determined by its social analysis rather than the Bible, but concluded that all true theology arises out of response to a situation and that this requires an understanding of that context. Genuine theology is never done in a vacuum. The Kairos Document represented theology from the perspective of those oppressed by colonialism and apartheid; it was a theology born out of struggle, a theology of the Soweto uprising rather than one emanating from the spheres of political and ecclesiastical power.

In conclusion Bethge considered the implications of the Kairos Document for the German church today. For him the danger could be summed up in two phrases that paralleled the "state" and "church" theologies of the Kairos Document - a theology of complicity (Komplizentum) and a docetic ecclesiology - which he regarded as two sides of the same coin. The first was a theology that gave support to the status quo in Germany, uncritically accepting the prevailing capitalist ideology; the second was an understanding of the church that stressed the "spiritual" at the cost of the concrete embodiment of the gospel, thereby avoiding dealing with the critical social and political issues.

In 1959 Bethge had observed the danger in Germany of regarding "thinking of the theology of the church struggle as only an interlude?"34 Yet now it appeared that the issues facing the church, whether in Germany, the United

33 Bethge had in mind Bonhoeffer's lecture to the first class of seminarians at Finkenwalde in 1936. On the Question of Church Communion.In Bonhoeffer, Dietrich 2013. Theological Education at Finkenwalde: 1935-1937. Minneapolis: Augsburg Fortress. 656-89.

34 Eberhard Bethge, "The Editing and Publishing of the Bonhoeffer Papers", in The Andover Newton Bulletin, 16. 
States, Britain or South Africa were recurrent ones, albeit in different guises. In addressing the South African situation, Bethge continually reminded his audiences that Bonhoeffer's legacy was to remember rightly the past in which he struggled to witness to the true meaning of Jesus Christ.

History had turned a complete circle. When Bethge came to South Africa the question was what could South Africans learn from the German Kirchenkampf and from the legacy of Bonhoeffer. But over the years the question had become what could and should Germans learn from the church struggle in South Africa, from the testimony of black theologians, the Belhar Confession, and now finally from the Kairos Document.

\section{A postscript}

In his Ethics Bonhoeffer wrote about Christians and secular humanists who, in standing for the truth and for justice found each other in the Resistance against Hitler. ${ }^{35}$ Increasingly as the years of the struggle passed, Naudé became involved with others in the liberation struggle who were not Christians, yet he found he had more in common with them in their concern for justice than he had with Christians who lacked that commitment. Then in his Letters and Papers from Prison Bonhoeffer wrote about "Christianity without religion." ${ }^{36}$ Although he never lost his deep Christian convictions or the genuine piety that shaped his earlier life and ministry, Naudé embodied something of this "true worldliness," or the "Christian humanism" to which Bonhoeffer was pointing. ${ }^{37}$ Whatever the similarities between their formation as Christians and pastors, or that of their respective roles in the church struggles in their countries, in the end they became models of a new style of being Christian in the world today that has inspired others. And it is this integrity in which word and

35 Dietrich Bonhoeffer, Ethics, Dietrich Bonhoeffer Works, vol. 6. (Minneapolis: Fortress 2005), 131-32.

36 Bonhoeffer, Letters and Papers from Prison. 362-64.

37 Bonhoeffer, Ethics, 400. See also John W de Gruchy, 2010. "Dietrich Bonhoeffer as Christian Humanist", in Being Human, Becoming Human: Dietrich Bonhoeffer and Social Thought (Zimmermann, Jensk and Gregor, Brian. Eugene, OR: Pickwick Publications 2010) 3-24. 
action, confession and resistance, are in harmony that finally unites them as human beings and Christians.

By the time of the 1996 International Bonhoeffer Congress in Cape Town, Eberhard's health prevented his attendance. But Beyers Naudé did attend and in his welcome speech at the opening service in St. George's Cathedral, he spoke about the abiding significance of the question Bonhoeffer raised in his Letters and Papers from Prison: "Who is Christ actually for us today?" 38 Seeking answers that question within their respective contexts and lives was what bound Bonhoeffer and Oom Bey together as authentic witnesses to the gospel. That challenge remains as we now, in 2015, celebrate the thirtieth anniversary of the Kairos Document.

38 Bonhoeffer, Letters and Papers from Prison, 362. 